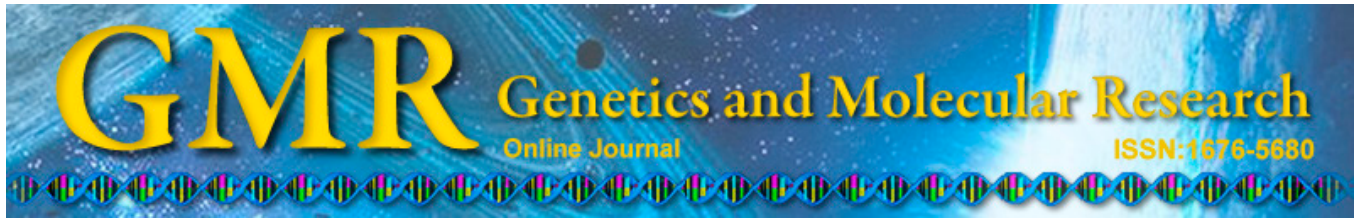

\title{
Identification and association of single-nucleotide polymorphisms in gonadotropin-inhibitory hormone ( $G n I H)$ gene with egg production traits in Erlang mountainous chickens
}

\author{
Y.D. Hu ${ }^{1 *}$, Q.K. Huang ${ }^{2 *}$, Q. Zhu ${ }^{1}$, D. Lan ${ }^{1}$, Z.Q. Feng ${ }^{1}$, L. Zhang ${ }^{1}$, \\ X. Lan' ${ }^{1}$ L. Ye ${ }^{1}$, Y.P. Liu ${ }^{1}$, M. He ${ }^{1}$ and H.B. Pu${ }^{1}$ \\ ${ }^{1}$ Farm Animal Genetic Resources Exploration and Innovation Key Laboratory \\ of Sichuan Province, Sichuan Agricultural University Ya'an, Sichuan, China \\ ${ }^{2}$ Guangyuan Food of Animal Husbandry Bureau, Guanyuan, Sichuan, China \\ *These authors contributed equally to this study. \\ Corresponding author: Y.P. Liu \\ E-mail: liuyp578@163.com
}

Genet. Mol. Res. 14 (1): 294-303 (2015)

Received March 26, 2014

Accepted October 6, 2014

Published January 23, 2015

DOI http://dx.doi.org/10.4238/2015.January.23.3

\begin{abstract}
Gonadotropin-inhibitory hormone $(G n I H)$ gene is an important gene in reproduction. In this study, we screened singlenucleotide polymorphisms (SNPs) in the chicken GnIH gene among 204 individuals in Erlang mountainous chickens. We then analyzed the associations between polymorphisms of the $\mathrm{GnIH}$ gene and 5 egg production traits in chickens. Five SNPs (T3305C, T3310C, G3403C, G3411A, and T3591C) were detected. Associations between polymorphic loci and age at first egg, body weight at first egg, weight at first egg, egg weight in 300 days, and egg production in 300 days were analyzed using analysis of covariance. The results showed that SNP1, SNP3, and SNP4 had large effects on age at first egg, while SNP5 had a large effect on body weight at first egg; of the effect of the TT genotype was significantly higher than that of CT $(\mathrm{P}<0.01)$. Further
\end{abstract}


analysis show that the highest frequency $(0.2353)$ haplotype H1H1 was associated with the latest age at first egg. The H4H5 haplotype had a positive effect on egg production in 300 days and a negative effect on weight at first egg. We observed no association between the $\mathrm{H} 3 \mathrm{H} 3$ haplotype and body weight at first egg.

Key words: Egg production; Erlang mountainous chicken; GnIH

\section{INTRODUCTION}

The gonadotropin-inhibitory hormone $(G n I H)$ gene is an important gene that is involved in the development of reproductive traits (Tsutsui et al., 2010a,b) and is a glycoprotein hormone (Tsutsui, 2009). GnIH as a novel Arge-Phe (RF) amide was first identified in the quail hypothalamus (Tsutsui et al., 2000). GnIH in the brain acts directly on the pituitary via the $G n I H$ receptor to inhibit gonadotropin release, indirectly inhibiting circulating luteinizing hormone (Shimizu and Bédécarrats, 2010) and stimulating the release of folliclestimulating hormone and prolactin in birds (Tsutsui et al., 2000; Mateos et al., 2002; Osugi et al., 2004; Bentley et al., 2006a; Tsutsui et al., 2006; Ubuka et al., 2006). Further, similar suppressive effect of $\mathrm{GnIH}$ on gonadotropin mRNA was associated with inhibition of both luteinizing hormone and follicle-stimulating hormone release in the chicken (Ciccone et al. 2004) and quail (Ubuka et al., 2006). GnIH affects reproductive traits by regulating these hormones during hatching (Ubuka et al., 2003). It may participate not only in neuroendocrine functions but also in behavioral (Tachibana et al., 2005; Bentley et al., 2006b) and autonomic mechanisms.

The suppressive effect of $G n I H$ on gonadotropin has not been thoroughly examined. There have been no investigations on the relationship between polymorphisms in the $G n I H$ gene and reproduction in chickens. Thus, we identified single-nucleotide polymorphisms (SNPs) in the chicken $G n I H$ gene and analyzed whether an association exists between polymorphisms in the $G n I H$ gene and egg production.

\section{MATERIAL AND METHODS}

\section{Chicken populations}

A total of 359 Erlang mountainous female chickens were included in this study. All chickens had free access to feed and water. Commercial corn-soybean diets that met all National Research Council requirements were provided in the study. At 300 days, approximately $2 \mathrm{~mL}$ blood was collected from the brachial vein of each individual. The next day, genomic DNA was isolated by phenolic extraction and used to genotype the GnIH gene.

\section{Egg production trait measurements}

Age at first egg was recorded when each hen began to lay. On the same day, the hen's body weights at first egg and weight at first egg were measured. Each hen's egg weight and egg numbers were recorded from the age at first egg to the age of 300 days. 


\section{DNA pool}

The DNA from each chicken was isolated and $5 \mu \mathrm{L}$ DNA from 30 birds was mixed together. This mixed DNA pool was used for amplification.

\section{Amplification and population genotyping}

Three polymerase chain reaction (PCR) primers were designed according to the sequence of Gallus gallus GnIH (GenBank accession No. AB193126) using the primer design program Oligo 6.0 and Primer 5.0. All primer sequences are shown in Table 1.

Table 1. PCR forward (F) and (R) primers for the $G n I H$ gene.
\begin{tabular}{llcc} 
\\
\hline Primer & Sequences (5'-3') & Annealing temperature & Length (bp) \\
\hline$P 1$ & F: GATGACAGCTTGCTTTTC & 56 & 264 \\
$P 2$ & R: TTCAGTGCTCAGGGTTTG & 56 & 524 \\
& F: AGTAGCTGGAATGGCACA & & 546 \\
& R: GAGAATCCTGAGGAAGG & 60 & \\
& F1: AGGGATGTGAATTCTAACGATCACATTC & & \\
& R: TCCCACAGTGCAGATGTAGGATGTTAG & & \\
& F2: AACTAAGGATCTTGAGAAGGGAATGT & & \\
& R2: TACAGCATGACTTTGGTAGATGATAT & & \\
\hline
\end{tabular}

EX3 used nested PCR.

PCR was performed in a final volume of $25 \mu \mathrm{L}$ containing $0.5 \mu \mathrm{L} 2.5 \mathrm{ng} / \mu \mathrm{L}$ genomic DNA, $0.5 \mu \mathrm{L} 10 \mu \mathrm{M}$ of each primer, $12.5 \mu \mathrm{L} 2 \mathrm{X}$ Master Mix (including $\mathrm{Mg}^{2+}$, dNTPs, Taq DNA polymerase). Amplification was carried out using the following procedure: initial denaturation at $94^{\circ} \mathrm{C}$ for $5 \mathrm{~min} ; 35$ cycles of $94^{\circ} \mathrm{C}$ for $45 \mathrm{~s}, 56^{\circ}-60^{\circ} \mathrm{C}$ for $35 \mathrm{~s}$, and $72^{\circ} \mathrm{C}$ for $40 \mathrm{~s}$; final elongation at $72^{\circ} \mathrm{C}$ for $2 \mathrm{~min}$.

The PCR products were sequenced by Beijing Liuhe Genomics Biological Technology Co., Ltd. (Beijing, China). The new SNPs were identified based on sequencing results.

\section{Statistical analysis}

Data were analyzed using the GLM procedures of SAS (SAS Institute, Inc., Cary NC, USA). Genetic effects were analyzed using a general linear model procedure in the SAS package, and the following model was used:

$$
\mathrm{Y}=\mu+\mathrm{Bi}+\mathrm{Si}+\mathrm{Gk}+\text { eijk }
$$

where $Y=$ dependent variable, $\mu$ = population mean, $B i=$ fixed effects of breed, $S j=$ fixed effects of sex, $G k=$ genotype value, and eijk = random error. The interaction $\mathrm{G} \times \mathrm{S}$ was not significant for any trait and therefore was not included in the model. Significant differences $(\mathrm{P}<0.05)$ were found among different genotypes by least square means using the Duncan multiple-range test. 


\section{Hardy-Weinberg test, haplotype construction, and linkage disequilibrium analysis}

Hardy-Weinberg equilibrium was analyzed using the Hardy-Weinberg test 3.0 software. Based on the 5 SNPs present in all 204 experimental birds, haplotypes were constructed using the PHASE 2.0 program to reconstruct haplotypes from the population data. Analysis of linkage disequilibrium was carried out using the online software SHEsis (http://analysis.bio-X. $\mathrm{cn} /$ SHEsisMain.htm).

\section{RESULTS}

\section{SNP genotypes of the chicken $G n I H$ gene}

PCR products were developed for screening individuals in the population. Three target gene fragments were sequenced and found to contain SNPs (Figure 1). Both the homozygous and heterozygous individuals of different genotypes were sequenced for further analysis. We identified 5 mutations, including a G/C mutation at position 3403 nucleotides (nt), T/C mutation at position 3305,3310 , and $3591 \mathrm{nt}$, respectively, and a G/A mutation at $3411 \mathrm{nt}$ in the DNA sequence of the chicken (accession No. SB193126) (Figure 1).

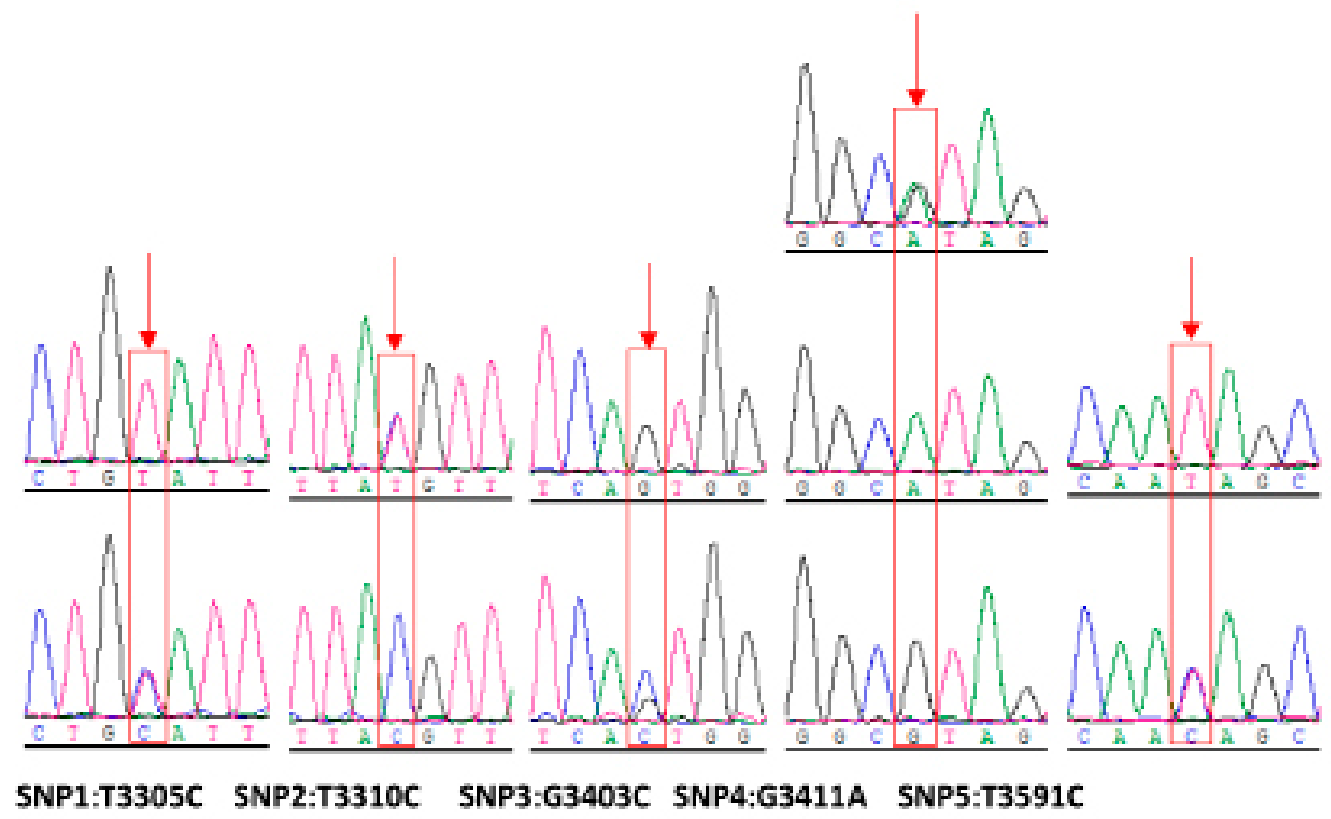

Figure 1. Sequencing results of the SNP1-5; arrow indicates the mutation site. SNP1: sequencing result of $\mathrm{T} / \mathrm{C}$ heterozygote and T/T homozygote at the 3305 site. SNP2: sequencing result of T/C heterozygote and $\mathrm{C} / \mathrm{C}$ homozygote at the 3310 site. SNP3: sequencing result of G/C heterozygote and G/G homozygote at the 3403 site. SNP4: sequencing result of A/G heterozygote and G/G homozygote at the 3411 site. SNP5: sequencing result of $\mathrm{T} / \mathrm{C}$ heterozygote and T/T homozygote at the 3591 site. 


\section{Frequencies of genotypes and alleles}

There was no CC homozygous genotype in SNP1, SNP3, and SNP5. The frequencies of the genotypes and alleles are shown in Table 2. In SNP1 and SNP3, the frequency of the TT homozygous genotype (0.7892) was higher than that of the TC heterozygous genotype (0.2108). The frequency of allele $\mathrm{T}(0.8946)$ was significantly higher than the $\mathrm{C}$ alleles $(0.1054)$. In SNP2, we observed no TT homozygous genotype. The frequency of the TC heterozygous genotype (0.1471) was lower than the CC homozygous genotype (0.8529). The frequency of allele $\mathrm{T}(0.0735)$ was significantly lower than of the $\mathrm{C}$ alleles $(0.9265)$. In SNP4, the frequency of the AG heterozygous genotype (0.6275) was significantly higher than the AA $(0.2402)$ and GG (0.1323) homozygous genotypes. In SNP5, the frequency of the TT heterozygous genotype (0.8578) was higher than the TC homozygous genotype (0.1422). The frequency of allele T (0.9289) was significantly higher than the C alleles (0.0711). All SNPs conformed to Hardy-Weinberg equilibrium $(\mathrm{P}>0.05)$, except SNP4. The polymorphic information content (PIC) of SNP4 was moderate $(0.25<$ PIC $<0.5)$, while the SNP PIC values were low (PIC $<$ $0.25)$.

\begin{tabular}{|c|c|c|c|c|c|c|c|c|}
\hline \multirow[t]{2}{*}{ SNPs } & \multirow{2}{*}{$\begin{array}{c}\text { Number } \\
204\end{array}$} & \multicolumn{2}{|c|}{ Gene frequency } & \multicolumn{3}{|c|}{ Genotype frequency } & \multirow[t]{2}{*}{$\chi^{2}$} & \multirow[t]{2}{*}{ PIC } \\
\hline & & $\mathrm{T}$ & $\mathrm{C}$ & TT & $\mathrm{TC}$ & $\mathrm{CC}$ & & \\
\hline SNP1 & & 0.8946 & 0.1054 & 0.7892 & 0.2108 & - & $2.831(\mathrm{P}=0.092)$ & 0.1708 \\
\hline & & $\mathrm{T}$ & $\mathrm{C}$ & $\mathrm{CC}$ & $\mathrm{TC}$ & TT & & \\
\hline SNP2 & & $\begin{array}{c}0.0735 \\
\mathrm{G}\end{array}$ & $\begin{array}{c}0.9265 \\
\mathrm{C}\end{array}$ & $\begin{array}{c}0.8529 \\
\text { GG }\end{array}$ & $\begin{array}{c}0.1471 \\
\text { CG }\end{array}$ & $\overline{\mathrm{CC}}$ & $1.285(\mathrm{P}=0.257)$ & 0.1269 \\
\hline SNP3 & & $\begin{array}{c}0.8946 \\
\text { A }\end{array}$ & $\begin{array}{c}0.1054 \\
\mathrm{G}\end{array}$ & $\begin{array}{c}0.7892 \\
\text { AA }\end{array}$ & $\begin{array}{l}0.2108 \\
\mathrm{AG}\end{array}$ & - & $2.831(\mathrm{P}=0.092)$ & 0.1708 \\
\hline SNP4 & & $\begin{array}{c}0.5539 \\
\mathrm{~T}\end{array}$ & $\begin{array}{c}0.4461 \\
\mathrm{C}\end{array}$ & $\begin{array}{c}0.2402 \\
\text { TT }\end{array}$ & $\begin{array}{c}0.6275 \\
\text { TC }\end{array}$ & $\begin{array}{c}0.1323 \\
\mathrm{CC}\end{array}$ & $14.48(\mathrm{P}<0.01)$ & 0.3721 \\
\hline SNP5 & & 0.9289 & 0.0711 & 0.8578 & 0.1422 & - & $1.914(\mathrm{P}=0.274)$ & 0.1233 \\
\hline
\end{tabular}

\section{Linkage disequilibrium analysis}

The results of linkage disequilibrium analysis are shown in Table 3 and Figure 2. SNP1 and SNP3 were in complete linkage disequilibrium $\left(D^{\prime}=1.000, r^{2}=1.000\right)$. There was no difference between these 2 SNPs, and thus we analyzed only 1 SNP. Others SNPs showed weak linkage disequilibrium $\left(\mathrm{r}^{2}<0.33\right)$.

Table 3. Linkage disequilibrium analysis of SNP loci of GnIH.

\begin{tabular}{llllll}
\hline Locus & SNP1 & SNP2 & SNP3 & SNP4 & SNP5 \\
\hline SNP1 & & 0.009 & 1.000 & 0.146 & 0.098 \\
SNP2 & 1.000 & 1.000 & 0.009 & 0.146 & 0.006 \\
SNP3 & 1.000 & 0.999 & 0.999 & 0.009 \\
SNP4 & 0.999 & 0.076 & 1.000 & 0.898 & 0.077 \\
SNP5 & 1.000 & &
\end{tabular}

$\mathrm{r}^{2}$ is above the diagonal for SNPs and $\mathrm{D}^{\prime}$ is below the diagonal. 

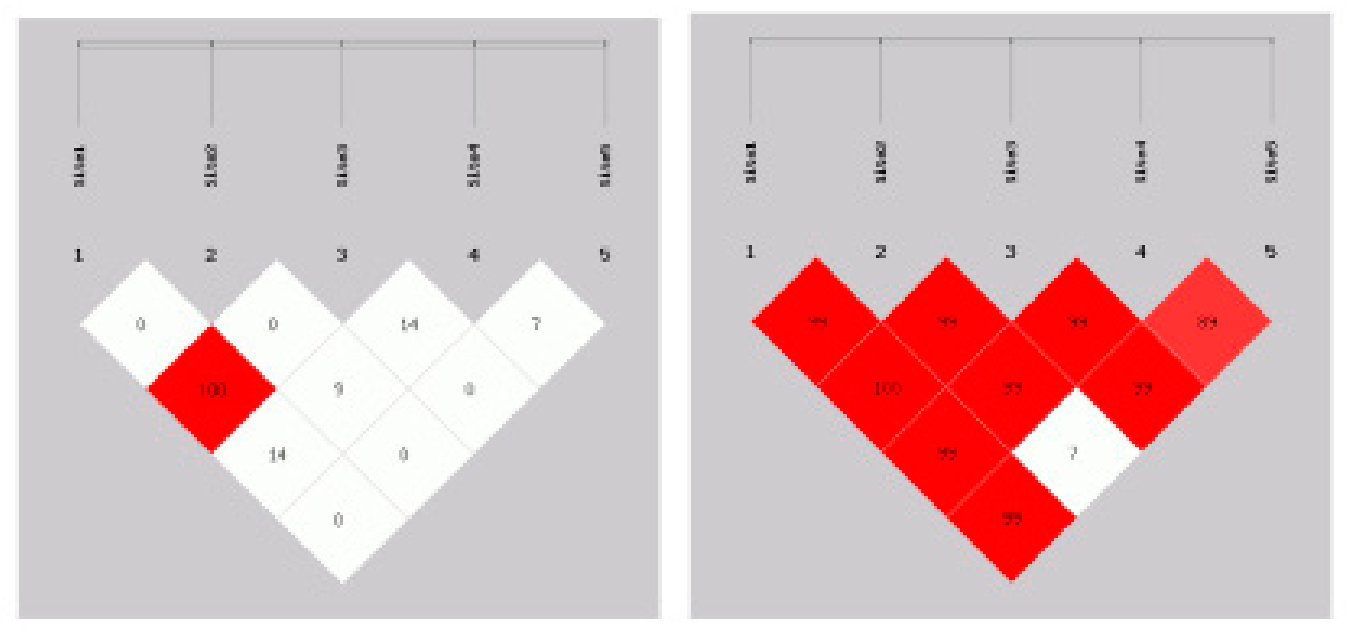

Figure 2. Map of $\mathrm{D}^{\prime}$ and $\mathrm{r}^{2}$. Left map indicate $\mathrm{r}^{2}$, right map indicate $\mathrm{D}^{\prime}$.

\section{Associations between SNPs in the GnIH gene and egg production traits}

The associations between the $G n I H$ genotypes and egg production traits in Erlang mountainous chickens were analyzed, and the least square means of 3 genotypes are listed in Table 4. The SNP1/SNP3 was significantly associated with age at first egg $(\mathrm{P}<0.01)$ and egg production in 300 days $(\mathrm{P}<0.05)$. Age at first egg in chickens with the TC/CG genotypes was significantly lower than that in those with TT/GG $(\mathrm{P}<0.01)$. Egg production in 300 days in chickens with the TC/CG genotypes was significantly higher than that in those with TT/GG $(\mathrm{P}<0.05)$. SNP2 was only significantly associated with egg production in 300 days, with TC significantly higher than $\mathrm{CC}(\mathrm{P}<0.05)$. SNP4 was significantly associated with 2 traits, age at first egg $(\mathrm{P}<0.01)$ and body weight at first egg $(\mathrm{P}<0.05)$. Both traits of AA were significantly higher than GG $(\mathrm{P}<0.05)$. SNP5 was significantly associated with body weight at first egg, with TT significantly higher than $\mathrm{CT}(\mathrm{P}<0.01)$.

\section{Haplotypes, construction of haplotypes, and their frequencies}

Haplotypes were constructed with 5 SNPs in all 204 experimental chicken, by employing the PHASE program to reconstruct haplotypes from population data. Table 5 shows that 6 haplotypes with minor allelic frequencies greater than $2 \%$ were identified based on these 5 SNPs. Three main haplotypes, H1, H3, and H6, accounted for $85.54 \%$ of the observations. Table 6 shows that 9 diplotypes were successfully constructed. Only the frequency of $\mathrm{H} 1 \mathrm{H} 2$ was lower than 0.01. Other diplotypes, H1H1, H1H6, H1H3, H1H4, H3H4, H1H5, and H4H5, were subjected to association analysis in this experiment.

\section{Construction of haplotypes and their associations with chicken egg production traits}

Mixed model analysis revealed significant associations between haplotypes with 4 traits, age at first egg, body weight at first egg, weight at first egg, and egg production in 300 
Y.D. Hu et al.

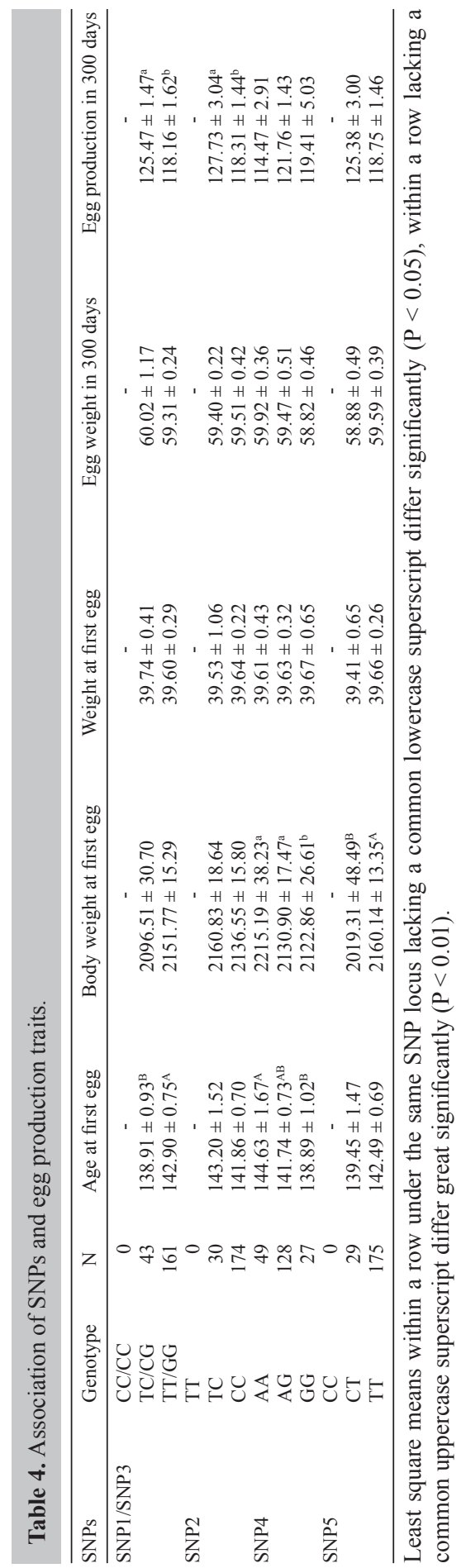


days (Table 7). The H3H4 haplotype had a negative effect on body weight at first egg, with the lowest body weight at first egg associated with earliest age at first egg. However, H1H1 showed the highest frequency $(0.2353)$ associated with latest age at first egg. The H4H5 haplotype had a positive effect on egg production in 300 days, negative effect on weight at first egg, highest egg production in 300 days, and lowest trait of weight at first egg. The results revealed that the $\mathrm{H} 3 \mathrm{H} 3$ haplotype had a positive effect on body weight at first egg.

Table 5. Haplotypes inferred based on the 5 single-nucleotide polymorphisms.
\begin{tabular}{lcccccc}
\hline Haplotype & SNP1 & SNP2 & SNP3 & SNP4 & SNP5 & Frequency \\
\hline H1 & T & C & G & A & T & 0.5515 \\
H2 & T & C & G & A & C & 0.0025 \\
H3 & T & C & G & G & T & 0.1985 \\
H4 & T & C & G & G & C & 0.0686 \\
H5 & T & T & G & G & T & 0.0735 \\
H6 & C & C & G & T & 0.1054 \\
\hline
\end{tabular}

Table 6. Hapoltype frequencies in $G n I H$.

\begin{tabular}{llllllllll}
\hline Diplotypes & H1H1 & H1H6 & H1H3 & H3H3 & H1H2 & H1H4 & H3H4 & H1H5 & H4H5 \\
\hline Frequency & 0.2353 & 0.2108 & 0.2206 & 0.0735 & 0.0049 & 0.0784 & 0.0294 & 0.1176 & 0.0294 \\
\hline
\end{tabular}

Table 7. Associations between diplotypes of the $G n I H$ gene and egg production traits.

\begin{tabular}{lrccccc}
\hline Diplotypes & $\mathrm{N}$ & $\begin{array}{c}\text { Age at first egg } \\
(\text { days })\end{array}$ & $\begin{array}{c}\text { Body weight at first } \\
(\mathrm{g})\end{array}$ & $\begin{array}{c}\text { Weight at first egg } \\
(\mathrm{g})\end{array}$ & $\begin{array}{c}\text { Egg weight in 300 days } \\
(\mathrm{g})\end{array}$ & $\begin{array}{c}\text { Egg production } \\
\text { in 300 days }(\text { days })\end{array}$ \\
\hline $\mathrm{H} 1 \mathrm{H} 1$ & 48 & $145.15 \pm 1.63^{\mathrm{A}}$ & $2128.13 \pm 26.63^{\mathrm{A}}$ & $39.63 \pm 0.44^{\mathrm{A}}$ & $59.95 \pm 0.37$ & $114.02 \pm 2.93^{\mathrm{BC}}$ \\
$\mathrm{H} 1 \mathrm{H} 6$ & 43 & $138.91 \pm 0.93^{\mathrm{AB}}$ & $2096.51 \pm 30.70^{\mathrm{A}}$ & $39.74 \pm 0.41^{\mathrm{A}}$ & $60.02 \pm 1.17$ & $125.47 \pm 1.47^{\mathrm{ABC}}$ \\
$\mathrm{H} 1 \mathrm{H} 3$ & 45 & $142.71 \pm 1.39^{\mathrm{AB}}$ & $2223.33 \pm 22.56^{\mathrm{A}}$ & $38.89 \pm 0.40^{\mathrm{A}}$ & $59.30 \pm 0.68$ & $118.04 \pm 3.04^{\mathrm{BC}}$ \\
$\mathrm{H} 3 \mathrm{H} 3$ & 15 & $140.80 \pm 1.42^{\mathrm{AB}}$ & $2249.33 \pm 40.18^{\mathrm{A}}$ & $40.47 \pm 0.76^{\mathrm{A}}$ & $58.10 \pm 0.91$ & $107.20 \pm 6.97^{\mathrm{C}}$ \\
H1H4 & 16 & $142.88 \pm 1.94^{\mathrm{AB}}$ & $2196.67 \pm 40.70^{\mathrm{A}}$ & $40.00 \pm 0.84^{\mathrm{A}}$ & $58.27 \pm 1.02$ & $117.75 \pm 3.36^{\mathrm{BC}}$ \\
H3H4 & 6 & $134.00 \pm 1.95^{\mathrm{B}}$ & $1913.75 \pm 56.99^{\mathrm{B}}$ & $41.83 \pm 1.01^{\mathrm{A}}$ & $58.83 \pm 0.54$ & $129.67 \pm 8.24^{\mathrm{AB}}$ \\
H1H5 & 24 & $144.25 \pm 1.84^{\mathrm{A}}$ & $2163.96 \pm 21.48^{\mathrm{A}}$ & $40.54 \pm 1.24^{\mathrm{A}}$ & $59.25 \pm 0.27$ & $124.75 \pm 3.50^{\mathrm{ABC}}$ \\
H4H5 & 6 & $139.00 \pm 1.47^{\mathrm{AB}}$ & $2148.33 \pm 39.36^{\mathrm{A}}$ & $35.50 \pm 0.50^{\mathrm{B}}$ & $60.00 \pm 0.43$ & $139.67 \pm 2.67^{\mathrm{A}}$ \\
\hline
\end{tabular}

Least squares means within a row under the same SNP locus lacking a common uppercase superscript differ great significantly $(\mathrm{P}<0.01)$.

\section{DISCUSSION}

GnIH interacts with some hormones relate to reproduction (Maddineni et al., 2008a; Sari et al., 2009). Thus, variations within genes have important effects on biological traits. Previous studies on the chicken genome have shown higher $G n I H$ expression at sexual maturity in chicken ovaries, diencephalon (Maddineni et al., 2008b), and follicular maturation (Maddineni et al., 2008a). In the chicken hypothalamus, pituitary, ovary, and oviduct, GnIH mRNA expression of broody and after brooding chickens was higher than that of laying hens (He, 2009). An increasing number of studies have focused on chicken $G n I H$ because of its role in central and peripheral reproductive function. Most of these studies demonstrated that GnIH is related to hormone regulation and reproduction, and lack of the SNPs is related to egg production. However, in the present study, 5 SNPs (T3305C, T3310C, G3403C, G3411A, 
and T3591C) were identified in Erlang mountainous chickens. Comparison of these SNPs revealed distinct mutation loci. SNP1, SNP3, and SNP4 had large effects on age at first egg, while SNP5 had large effects on body weight at first egg.

There are some limitations to single-marker analysis, such as noise, which obscures the results. Significant associations between individual SNPs and phenotypic traits were analyzed by single-factor analysis, not mixed model analysis. Therefore, it was unclear whether an association between the SNPs and the examined traits exists. Haplotype or haplotype blocking provided a practical solution for overcoming these limitations. Haplotypes were constructed for 5 SNPs and used to analyze the associations between haplotype combinations and 5 egg production traits.

Based on our results, chickens with the $\mathrm{H} 1 \mathrm{H} 1$ and $\mathrm{H} 3 \mathrm{H} 3$ haplotypes began laying later and the total of 300-days eggs were lower. The frequency of $\mathrm{H} 1$ was $55.15 \%$ and $\mathrm{H} 3$ was $19.85 \%$; these haplotypes may be disadvantageous for improving egg production traits.

However, the H4H5 haplotype combination should be advantageous for improving egg production traits. This result implies that an interaction exists between different SNPs. Our data showed that associations between haplotypes and egg production were more accurate than those for single SNPs, and that the haplotypes generally provided more information than did 1 SNP.

In summary, commercial breeding programs for layer chicken have become increasingly complex, making the use of molecular marker-assisted selection methods for improving reproduction important. Our results indicated that 5 SNP markers were associated with egg production, and thus the $G n I H$ gene plays an important role in regulating egg production in chickens. The $G n I H$ gene shows great potential for use in molecular marker-assisted selection programs for controlling egg production.

\section{ACKNOWLEDGMENTS}

Research supported by the Key Projects of Sichuan Province Education Office (\#14ZA0021), the Project of the Application Basis Project from the Science and Technology Department of Sichuan Province (\#2014JY0163), and the Project of National Natural Science Foundation of China (\#31402068).

\section{REFERENCES}

Bentley GE, Jensen JP, Kaur GJ, Wacker DW, et al. (2006a). Rapid inhibition of female sexual behavior by gonadotropininhibitory hormone (GnIH). Horm. Behav. 49: 550-555.

Bentley GE, Kriegsfeld LJ, Osugi T, Ukena K, et al. (2006b). Interactions of gonadotropin-releasing hormone (GnRH) and gonadotropin-inhibitory hormone $(\mathrm{GnIH})$ in birds and mammals. J. Exp. Zool. A Comp. Exp. Biol. 305: 807-814.

Ciccone NA, Dunn IC, Boswell T, Tsutsui K, et al. (2004). Gonadotrophin inhibitory hormone depresses gonadotrophin $\alpha$ and follicle-stimulating hormone $\beta$ subunit expression in the pituitary of the domestic chicken. J. Neuroendocrinol. 16: 999-1006.

He ZI (2009). Relationship in Expression of Laying hen GnRH, GnIH, VIP Gene and Laying Performance. Master's thesis, Nanjing Agricultural University, Nanjing.

Maddineni SR, Ocón-Grove OM, Krzysik-Walker SM, Hendricks GL 3rd, et al. (2008a). Gonadotrophin-inhibitory hormone receptor expression in the chicken pituitary gland: potential influence of sexual maturation and ovarian steroids. J. Neuroendocrinol. 20: 1078-1088.

Maddineni SR, Ocon-Grove OM, Krzysik-Walker SM, Hendricks GL 3rd, et al. (2008b). Gonadotropin-inhibitory hormone $(\mathrm{GnIH})$ receptor gene is expressed in the chicken ovary: potential role of $\mathrm{GnIH}$ in follicular maturation. Reproduction 135: 267-274. 
Mateos J, Mañanos E, Carrillo M and Zanuy S (2002). Regulation of follicle-stimulating hormone (FSH) and luteinizing hormone $(\mathrm{LH})$ gene expression by gonadotropin-releasing hormone $(\mathrm{GnRH})$ and sexual steroids in the Mediterranean Sea bass. Comp. Biochem. Physiol. B Biochem. Mol. Biol. 132: 75-86.

Osugi T, Ukena K, Bentley G, O'Brien S, et al. (2004). Gonadotropin-inhibitory hormone in Gambel's white-crowned sparrow (Zonotrichia leucophrys gambelii): cDNA identification, transcript localization and functional effects in laboratory and field experiments. J. Endocrinol. 182: 33-42.

Sari IP, Rao A, Smith JT, Tilbrook AJ, et al. (2009). Effect of RF-amide-related peptide-3 on luteinizing hormone and follicle-stimulating hormone synthesis and secretion in ovine pituitary gonadotropes. Endocrinology 150: 5549-5556.

Shimizu M and Bédécarrats GY (2010). Activation of the chicken gonadotropin-inhibitory hormone receptor reduces gonadotropin releasing hormone receptor signaling. Gen. Comp. Endocrinol. 167: 331-337.

Tachibana T, Sato M, Takahashi H, Ukena K, et al. (2005). Gonadotropin-inhibiting hormone stimulates feeding behavior in chicks. Brain Res. 1050: 94-100.

Tsutsui K (2009). A new key neurohormone controlling reproduction, gonadotropin-inhibitory hormone $(\mathrm{GnIH})$ : Biosynthesis, mode of action and functional significance. Prog. Neurobiol. 88: 76-88.

Tsutsui K, Saigoh E, Ukena K, Teranishi H, et al. (2000). A novel avian hypothalamic peptide inhibiting gonadotropin release. Biochem. Biophys. Res. Commun. 275: 661-667.

Tsutsui K, Ubuka T, Yin H, Osugi T, et al. (2006). Mode of action and functional significance of avian gonadotropininhibitory hormone (GnIH): a review. J. Exp. Zool. A Comp. Exp. Biol. 305: 801-806.

Tsutsui K, Bentley G, Kriegsfeld L, Osugi T, et al. (2010a). Discovery and evolutionary history of gonadotrophin-inhibitory hormone and kisspeptin: new key neuropeptides controlling reproduction. J. Neuroendocrinol. 22: 716-727.

Tsutsui K, Bentley GE, Bedecarrats G, Osugi T, et al. (2010b). Gonadotropin-inhibitory hormone (GnIH) and its control of central and peripheral reproductive function. Front. Neuroendocrinol. 31: 284-295.

Ubuka T, Ueno M, Ukena K and Tsutsui K (2003). Developmental changes in gonadotropin-inhibitory hormone in the Japanese quail (Coturnix japonica) hypothalamo-hypophysial system. J. Endocrinol. 178: 311-318.

Ubuka T, Ukena K, Sharp PJ, Bentley GE, et al. (2006). Gonadotropin-inhibitory hormone inhibits gonadal development and maintenance by decreasing gonadotropin synthesis and release in male quail. Endocrinology 147: 1187-1194. 